\title{
Retraction Note: LncRNA TUG1 was upregulated in osteoporosis and regulates the proliferation and apoptosis of osteoclasts
}

\author{
Ye Han ${ }^{1}$, Chunying Liu' ${ }^{2}$ Ming Lei ${ }^{1}$, Shaosong Sun ${ }^{1}$, Wenkui Zheng ${ }^{1}$, Yanan Niư ${ }^{1}$ and Xi Xia ${ }^{3^{*}}$
}

\section{Retraction Note: J Orthop Surg Res (2019) 14:416 https://doi.org/10.1186/s13018-019-1430-4}

The Editor-in-Chief has retracted this article [1] due to lack of evidence that the study has received ethics approval. After publication it has come to the Editor's attention that in the body of the article the authors state that their study was approved by Baoding First Central Hospital. However, in the Ethics declarations section, the authors state that their study was approved by the Ethics Committee of the Maternity and Child Care Center of Liuzhou. The authors have not provided documentation of approval from an ethics committee for this study. The authors have not responded to any correspondence regarding this retraction.

\section{Author details}

'Department of Orthopaedics, Affiliated Hospital of Hebei University, Baoding City 071000 , Hebei Province, People's Republic of China. ${ }^{2}$ Department of Pharmacology, School of Clinical Medicine, Hebei University, Baoding City 071000, Hebei Province, People's Republic of China. ${ }^{3}$ Department of Orthopaedics, Baoding First Central Hospital, No. 320, Great Wall North Street, Baoding City 071000, Hebei Province, People's Republic of China.
Published online: 12 October 2020

\section{Reference}

1. Han Y, et al. LncRNA TUG1 was upregulated in osteoporosis and regulates the proliferation and apoptosis of osteoclasts. J Orthop Surg Res. 2019;14: 416 https://doi.org/10.1186/s13018-019-1430-4.

* Correspondence: gqjab89@163.com

${ }^{3}$ Department of Orthopaedics, Baoding First Central Hospital, No. 320, Great

Wall North Street, Baoding City 071000, Hebei Province, People's Republic of China

Full list of author information is available at the end of the article

(c) The Author(s). 2020 Open Access This article is licensed under a Creative Commons Attribution 4.0 International License, which permits use, sharing, adaptation, distribution and reproduction in any medium or format, as long as you give appropriate credit to the original author(s) and the source, provide a link to the Creative Commons licence, and indicate if changes were made. The images or other third party material in this article are included in the article's Creative Commons licence, unless indicated otherwise in a credit line to the material. If material is not included in the article's Creative Commons licence and your intended use is not permitted by statutory regulation or exceeds the permitted use, you will need to obtain permission directly from the copyright holder. To view a copy of this licence, visit http://creativecommons.org/licenses/by/4.0/. The Creative Commons Public Domain Dedication waiver (http://creativecommons.org/publicdomain/zero/1.0/) applies to the data made available in this article, unless otherwise stated in a credit line to the data. 